\title{
An Unusual Presentation of Esthesioneuroblastoma in a Young Pregnant Female
}

\author{
Meenakshi Wadhwani ${ }^{a} \quad$ Amar Ranjan $^{\mathrm{b}} \quad$ Kulbhushan Gangwani $^{\mathrm{d}}$ Prasenjit Das $^{\mathrm{c}}$ \\ ${ }^{a}$ Dr Rajendra Prasad Centre for Ophthalmic Sciences, ${ }^{b}$ Dr B.R. Ambedkar Institute Rotary Cancer Hospital, and \\ 'Department of Pathology, All India Institute of Medical Sciences, and ${ }^{d}$ R.B. Medical Centre, New Delhi, India
}

\section{Established Facts}

- It is marked by aggressive presentation.

- It spreads to orbit.

\section{Novel Insights}

- Primarily ocular sign with blindness in one eye at presentation.

- The tumor may present without nasal symptom.

\section{Keywords}

Esthesioneuroblastoma - Olfactory neuroblastoma · Neuroepithelium · Neuroectodermal tumor

\begin{abstract}
Background: Esthesioneuroblastoma is a rare neuroepithelial tumor arising from the olfactory epithelium in the cribriform plate or nasal cavity. It accounts for $1-5 \%$ of cases of malignant neoplasms of the nasal cavity. Methods: A 20-yearold pregnant female presented with painful loss of vision in both eyes, on imaging diagnosed as meningioma. There was a progressive increase in pain along with diminution of vision to the extent of complete loss of vision in the right eye. Results: In view of increasing proptosis with progressive
\end{abstract}

๑) 2017 S. Karger AG, Basel

E-Mail karger@karger.com www.karger.com/oop complete loss of vision in the left eye also, she consulted the neurosurgery department at a tertiary care hospital where a follow-up of contrast-enhanced computerised tomography was made. Histopathology of fluid obtained after craniotomy showed esthesioneuroblastoma. In view of intracranial space-occupying lesion applying pressure on the optic nerve, intravenous methylprednisolone ( $1 \mathrm{~g}$, IV stat $X 3$ days) was given. She underwent extensive radiotherapy but died within 3 months of diagnosis. Conclusion: This case highlights the progressive and fatal course of olfactory neuroblastoma. As it can present with the complex symptoms related to ocular and nasal sites, timely referral of patients presenting with visual symptoms along with nasal involvement (frequent epistaxis) to otorhinolaryngologists is very important.

(c) 2017 S. Karger AG, Basel 


\section{Introduction}

Esthesioneuroblastoma (ENB, olfactory neuroblasto$\mathrm{ma}$ ) is an uncommon neuroepithelial tumor that originates from the olfactory sensory epithelium in the upper nasal fossa at the level of the cribriform plate. It was described first by Berger et al. in 1924 [1, 2]. It frequently invades the cranial base, cranial vault, and orbit. It has a histological pattern similar to that of sympathetic ganglia, retina, and adrenal medulla $[3,4]$. It differs from most of neuroectodermal tumors that occur in childhood by having a peak distribution between 11-20 years and 51-60 years of age $[2,3]$. We report a rare presentation of ENB in a pregnant female presenting with complete unilateral loss of vision in one eye and ultimately leading to death within 3 months of diagnosis.

\section{Case Presentation}

A 20-year-old pregnant female presented to the outpatient department with complaints of painful diminution of vision in the right eye followed by complete loss of vision in the right eye within 2 days. The pain increased with ocular movements. There was no history of trauma, coloured halos, redness, photophobia, or floaters and no history of drug intake or any systemic diseases.

On ocular examination, visual acuity in OD was absent perception of light and in OS 6/12 with accurate projection of rays. On anterior segment examination, there was mild proptosis, RAPD grade I in OD. On posterior segment examination, there was mild disc hyperemia, and the rest of the fundus examination was within normal limits. There was no restriction of ocular movements in the right eye. In the left eye, anterior and posterior segment examination was within normal limits. On general physical examination, she was primigravida with 38 weeks' period of gestation. Her obstetric examination and hematological examination were within normal limits. A provisional diagnosis of retrobulbar neuritis was
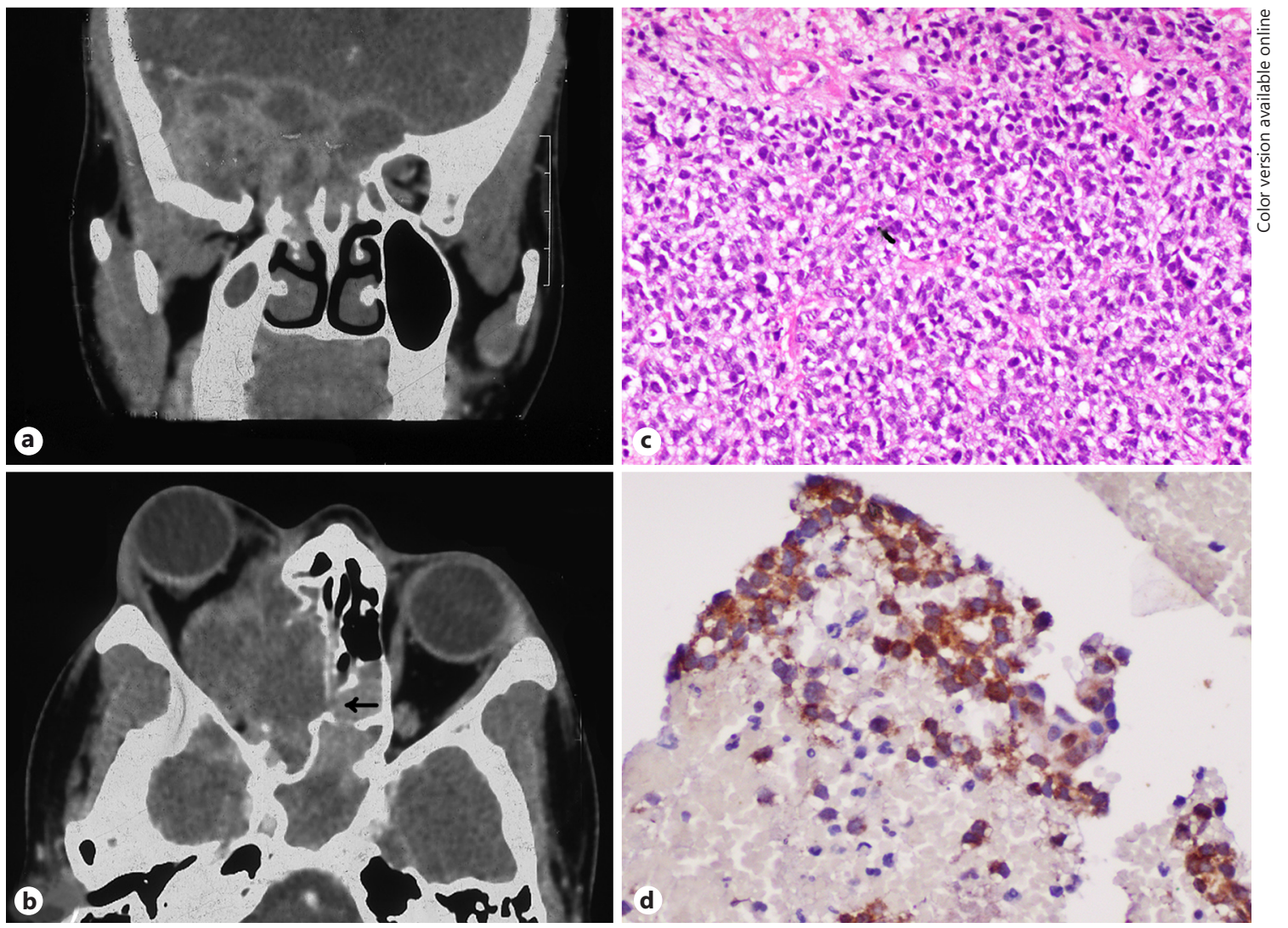

Fig. 1. a, b Computed tomography scan (axial and coronal section) of the orbit showing a heterogeneously enhancing basifrontal space-occupying cystic component epicentered around olfactory fossa extending to anterior and middle cranial fossa. The mass is causing erosion of right medial and superior wall of right orbit. The mass is also seen to be extending into right orbit with displacement of medial rectus and encasement of right optic nerve. c Mi- crophotograph of the section from nasal cavity shows tumor cells in sheets with occasional rosettes. Cells are monomorphic with high nuclear cytoplasmic ratio, hyperchromatic nuclei with moderate to scant cytoplasm. d Immunohistochemistry shows cytoplasmic NSE positivity whereas synaptophysin, cytokeratin, GFAP, desmin are negative. 
Table 1. Clinical presentation, pathology, imaging, and treatment outcomes of patients with esthesioneuroblastoma

\begin{tabular}{|c|c|c|c|c|c|c|c|}
\hline $\begin{array}{l}\text { Author, } \\
\text { year }\end{array}$ & $\begin{array}{l}\text { Age, } \\
\text { gender }\end{array}$ & Presenting sign & Laterality & Imaging & $\begin{array}{l}\text { Histopathological } \\
\text { markers }\end{array}$ & Treatment & Prognosis \\
\hline $\begin{array}{l}\text { Rakes } \\
\text { et al., } 1985 \\
{[9]}\end{array}$ & $64, \mathrm{~F}$ & $\begin{array}{l}\text { Right eye proptosis, } \\
\text { nasal discharge }\end{array}$ & Unilateral & $\begin{array}{l}\text { Mass at the apex of } \\
\text { orbit contiguous } \\
\text { with ethmoid sinus }\end{array}$ & $\begin{array}{l}\text { Histopathologically } \\
\text { positive (details not } \\
\text { given) }\end{array}$ & $\begin{array}{l}\text { Surgery and } \\
\text { radiotherapy }\end{array}$ & $\begin{array}{l}\text { Died after } \\
11 \text { months } \\
\text { of diagnosis }\end{array}$ \\
\hline $\begin{array}{l}\text { Lee and } \\
\text { Tang, } 2000 \\
{[8]}\end{array}$ & $52, \mathrm{M}$ & $\begin{array}{l}\text { Left-sided ptosis, } \\
\text { left third nerve } \\
\text { palsy, left nasal } \\
\text { bleeding }\end{array}$ & Unilateral & $\begin{array}{l}\text { 4-cm mass in left } \\
\text { sphenoid sinus } \\
\text { extending into } \\
\text { prepontine cistern, } \\
\text { sellar area, } \\
\text { cavernous sinus, and } \\
\text { dorsum sellae }\end{array}$ & $\begin{array}{l}\text { Synaptophysin } \\
\text { positive }\end{array}$ & Surgery & $\begin{array}{l}\text { Alive after } \\
18 \text { months } \\
\text { of follow-up }\end{array}$ \\
\hline $\begin{array}{l}\text { Villalba } \\
\text { et al., } 2008 \\
\text { [7] }\end{array}$ & $85, \mathrm{~F}$ & Eyelid edema & Unilateral & $\begin{array}{l}\text { Intrasinusal solid } \\
\text { mass spreading to } \\
\text { anterior cranial fossa }\end{array}$ & $\begin{array}{l}\text { Histopathologically } \\
\text { positive (details not } \\
\text { given) }\end{array}$ & $\begin{array}{l}\text { Palliative } \\
\text { treatment }\end{array}$ & $\begin{array}{l}\text { Died within } \\
2 \text { months of } \\
\text { diagnosis }\end{array}$ \\
\hline $\begin{array}{l}\text { Aggarwal } \\
\text { et al., } 2011 \\
{[1]}\end{array}$ & $17, \mathrm{M}$ & $\begin{array}{l}\text { Right eye proptosis, } \\
\text { bilateral neck } \\
\text { metastasis }\end{array}$ & Unilateral & $\begin{array}{l}\text { Heterogeneous soft } \\
\text { tissue mass involving } \\
\text { right nasal sinus, } \\
\text { anterior and } \\
\text { posterior ethmoids, } \\
\text { erosion of cribriform } \\
\text { plate }\end{array}$ & Not mentioned & Radiotherapy & $\begin{array}{l}\text { Alive after } \\
2 \text { months of } \\
\text { treatment }\end{array}$ \\
\hline
\end{tabular}

made. On computerised tomography scan of the brain and orbit, a provisional diagnosis of meningioma was made. In view of intracranial space-occupying lesion applying pressure on the optic nerve, intravenous methylprednisolone (1 g, IV stat $\mathrm{X} 3$ days) was given and she was discharged without any improvement in her visual acuity. Thereafter, she was referred to the neurosurgery department. After 2 weeks, she gave birth to a healthy baby boy by vaginal route and consulted the neurosurgery department.

In view of increasing proptosis with progressive complete loss of vision in the left eye also, she consulted the neurosurgery department at a tertiary care hospital there a follow-up of contrast-enhanced computerised tomography (Fig. 1a, b) scan of the brain revealed a heterogeneously enhancing right basifrontal space-occupying lesion with extension to the orbit and erosion of the meatal wall. She underwent right orbitoparietal craniotomy and subtotal tumor excision and a repeat craniotomy within a week. Histopathology of the tumor mass revealed ENB (Kadish grade C) (Fig. 1c, d) and she was planned for radiotherapy in the form of supportive care. She underwent three cycles of external beam radiotherapy but died after the third cycle due to multiple organ failure.

\section{Discussion}

The most common manifestations of ENB are epistaxis and nasal obstruction due to frequent nasal and sinus involvement. The other symptoms may vary between 
headache, lacrimation, anosmia, and visual disturbance due to proptosis and optic neuropathy. Contrary to this, the index case presented with visual symptoms with no nasal symptoms. ENB is known to occur with equal frequency in females and males. The tumor has a tendency of rapid progression submucosally in all directions with the involvement of the nasal sinus and nasal cavity.

There are numerous classifications for staging ENB, but the most commonly followed is the one by Kadish et al. [2] since 1976 with 3 stages (A, B, C), but recently, Morita et al. [4] added stage $D$ to it with metastases in the cervical lymph nodes $[2,3]$. Histopathological diagnosis is important to differentiate this tumor from other lesions such as lymphoma, meningioma, undifferentiated carcinoma, extramedullary plasmacytoma, or embryonal rhabdomyosarcoma [6]. Histopathologically, ENB is characterized by the presence of neuroepithelial cells arranged in a classic pseudorosette and rosette pattern, fibrillar intracellular background, and marked microvascularity.

The current treatment approach of surgery (en bloc tumour excision) and radiotherapy together or surgery followed by radiotherapy has good prognosis but is associated with poor outcome in the presence of female gender, age over 50 years, and distant metastasis $[3,4]$. It has a very aggressive and fatal course, a 5-year survival rate of approximately $45-50 \%$ has been reported by Dulguerov et al. [5], and it has a metastatic predilection for cervical lymph nodes and lungs.

There are many cases in the literature of ENB presenting with visual symptoms, but most of them had manifestations in the form of primary nasal symptoms along with associated visual symptoms (Table 1), except the one reported by Lopez et al. [6] presenting with exclusive orbital manifestation and Aggarwal et al. [1] presenting with proptosis and no nasal symptoms at presentation, but in both cases, the patients were stable after treatment. The index case also presented with orbital manifestation in the form of mild proptosis and unilateral visual loss progressing to blindness and death within 3 months of diagnosis in spite of treatment.

\section{Conclusion}

This case highlights the progressive and fatal course of olfactory neuroblastoma as they can present with the complex symptoms related to ocular and nasal sites. Imaging and histopathology can aid in the timely diagnosis of this malignancy. It is necessary for ophthalmologists to remain aware of this disease as they play a very important role in the management of this entity by timely referral of patients presenting with visual symptoms along with nasal involvement (frequent epistaxis) to otorhinolaryngologists.

\section{Statement of Ethics}

Informed consent was taken from the patient's relative.

\section{Disclosure Statement}

There is no conflict of interest between the authors.

\section{References}

1 Aggarwal SK, Kumar R, Shrivastav A, Keshri A, Sharma P: Esthesioneuroblastoma presenting with proptosis and bilateral neck metastasis: an unusual presentation. J Pediatr Neurosci 2011;6:78-81.

2 Berger L, Luc G, Richard D: L'esthesioneuroepitheliome olfactif. Bull Assoc Fr Etud Cancer 1924;13:410-421.

3 Kadish S, Goodman M, Wang C: Olfactory neuroblastoma: a clinical analysis of 17 cases. Cancer 1976;37:1571-1576.
4 Morita A, Ebersold MJ, Olsen KD, Foote RL, Lewis JE, Quast LM: Esthesioneuroblastoma: prognosis and management. Neurosurgery 1993;32:706-714.

5 Dulguerov P, Allal A S, Calcaterra TC: Esthesioneuroblastoma; a meta-analysis and review. Lancet Oncol 2001;2:683-690.

6 Lopez R, Mazzoni L, Chaput B, Jalbret F: Olfactory neuroblastoma presenting with exclusive orbital manifestations. J Craniofac Surg 2013;24:667-669.
7 Villalba RD, Ruiz MG, Vazquez CI, Quiros CM, Ruiz MC, Amador AR: Ophthalmic presentation of two cases of esthesioneuroblastoma. Arch Soc Esp Oftalmol 2008;83:317320 .

8 Lee AG, Tang RA: Third nerve palsy as the presenting manifestation of esthesioneuroblastoma. J Neuroophthalmol 2000;20:20-21.

9 Rakes SM, Yeatts RP, Campbell RJ: Ophthalmic manifestations of esthesioneuroblastoma. Ophthalmology 1985;92:1749-1753. 